\title{
Students' Output in the Distance Learning in Relation to the Teachers' Subjectivity in the Times of Pandemic: A Descriptive Study
}

\author{
Lemuel - Kim A. Garcia \\ Teacher, Magpapalayok National High School, Department of Education, Philippines \\ San Leonardo, Nueva Ecija, Philippines, 3102 \\ *Corresponding author details: Lemuel Kim A. Garcia
}

\begin{abstract}
The CoViD-19 pandemic has brought change to everything including the landscape of education. It has changed the way how the teachers teach, and the students learn. Due to the different challenges bought by this phenomenon, consideration atop of everything is done including assessment. This study aims to determine the subjectivity of the teachers in assessment in the new normal. This determines whether the challenges in the new normal specifically the channels and forms of assessment influences the teachers' subjectivity in assessing the students. To achieve this, the study determined the demographic profile, assessment practice, perception on the output of the students in the new normal and their standards in assessment. Mixed method research design was used in the study. It was found that there is relationship between the educational attainment and the teachers' preference on what to be checked more carefully - hardcopy or softcopy. The teachers' designation shows that it has a relationship regarding the view on whether to set a maximum and minimum grade limit in assessing the students. Moreover, there is a correlation between the teachers' perception and their standards in assessment. This study suggests that what the teachers perceive has something to do with their assessment standard. Thus, if they perceive to be more subjective (which the respondents agree as a result of this study) in these times of pandemic, they will be subjective in standardizing their assessment.
\end{abstract}

Keywords: assessment; subjectivity in assessment; distance learning; learning in the new normal; standard in assessment

\begin{abstract}
INTRODUCTION
The Philippines has been facing one of its biggest challenges so far, the Corona Virus Disease 2019 (CoViD19) pandemic. It has changed the world tremendously, from the way people live down to the forces where most of us depend on - economy, lifestyle and education. The latter has not been exempted from the challenge. Hence, education has to face a new challenge, the continuity of learning amidst a crisis.
\end{abstract}

As stated by the Universal Declaration of Human Rights [1], education is a right that everyone deserves regardless of who we are or what we experience thus it should be always available.

In the Philippines, the constitution specified in its article XIV section 2 [2] that the country should establish, maintain and support a system of education that is relevant to the needs of the society. Hence, the state is mandated to continue its education system for all its citizens amidst an emergency, CoViD-19.

In response to this, the Department of Education has created the Basic Education Learning Continuity Plan (BE-LCP) that covers the Most Essential Learning Competencies (MELCS), the different learning modalities, the health standards in schools and workplaces, special activities, and partnership [3]. This will be the bible of the country's educational bureau for the school year 2020-2021.

With the BE-LCP's introduction of the "New Normal" in education, adjustments were made - from the curriculum down to financial support - to ensure the continuity of education thus ensuring that quality education is always accessible to Filipino citizens [3]. Hence, education should continue while putting the health of the educational community (i.e., parents, students, school personnel as stipulated in the Batas Pambansa Blg. 232) [4] as the primary concern.

Since CoViD-19 is a contagious disease, the teaching and learning traditional way - face to face learning has been decided to be changed and is discouraged. Aside from adjusting the competencies in the curriculum guide of the K-12 into most essential ones, the Department of Education put into high regard the learning modalities to be used in the "New Normal".

Different modalities are introduced to the teachers to cope up with the new standards of the new normal. Since faceto-face classes are discouraged especially to areas that are under the Moderate and High-risk severity grading (BELCP p.30) [3], distance learning is introduced. As defined by DO 21, s. 2019 [5] as cited in the National Educators' Academy of the Philippines (NEAP) module 3a of Learning Delivery Module 2 [6], distance learning is a learning delivery where learners accomplish or access the given materials or resources as $\mathrm{s} /$ he learns at home or another venue aside from the school.

Afar from the classroom setting, the students are expected to learn in other physical learning spaces available as they access learning materials via online, digital, or printed copies (Ibid.) [6]. 
They are monitored and supervised by their teachers as their parents/ guardians (known as learning co-facilitators) facilitate their learning at home or in any place geographically absent from the classroom (BE-LCP p.31) [3].

There are four types of distance learning: Modular Distance Learning (MDL), Online Distance Learning (ODL), TV-based Instruction and Radio-based Instruction (Ibid.). All of these are implemented outside the classroom in case of face-to-face learning is not feasible due to an emergency or a crisis.

Because of the unprecedented changes in the education framework, the NEAP targeted to capacitate the teachers in the different learning modalities to ensure a seamless transition of the learning delivery amidst the change of the landscape of education (DO 12, s. 2020 p.4) [3].

Based on the update of the Department of Education as of June 25, 2020, as cited by Inquirer.net [7], 40 percent of the 800,000 teachers were already trained in distance learning to equip the teachers as they prepare for the opening of classes [7]. But recently, the Department of Education through NEAP has conducted Learning Delivery Modality Capacity Building Program [through OSEC-NEAP-OD2020-0827] that aims to ready the teachers and the school leaders on managing and being informed on the different learning modalities; this was done all over the country thus, all teachers in the public education sector were trained with DL.

With this, it is assumed that the teachers have an idea of what will happen in the new normal classes. However, the educational transition from what we use to had to a landscape that most teachers are unfamiliar with is a big challenge. According to Kamalludee (2020) [8], changes in the education framework are the shift of learning space, learning delivery, responsibility, and even in learning evaluations.

School personnel were trained in the delivery of learning, but learning does not stop there but in evaluation of each session of the teacher with his/ her students because this will be the basis of whether they have obtained the standard of the curriculum or not (DO 8, s.2015) [9].

Since the education system has immediately changed its landscape, assessment adjustments were expected. In the article of Kamalludee (2020) [8], alternative means of learning evaluation will be focused on assessment for learning - formative assessment - which concerns the understanding of students' knowledge and skills; than assessment of learning - summative assessment - which is used to report the progress of the students as defined by Dubec (2019) [10]. As per DO 8, s. 2015 [9], formative assessment can be given by the teacher at any time during the teaching and learning process. Hence, the self - learning materials given to the students have activities that would help them, their parents, and their teachers regarding their progress since it is based on Alternative Delivery Mode Standards which states that ADM learning materials help the student get immediate feedback, make them responsible to their learning, lead them to reflect on their learning experiences, etc (ADM LR Standards, 2020) [11].

To make the assessment method relevant to the situation that the country is in, a guideline was made exclusively for this pandemic - the Interim Guidelines for Assessment and Grading in Light of the BE - LCP (DepEd Order 31, s. 2020). In this order, some of the guidelines of DO 8, s. 2015 were suspended. The provisions of the said order focus on conducting assessment in distance learning while not compromising the quality of assessment to attain the set objectives of the teachers.
Do 31, s. 2020 [22] provides that the teachers are allowed to design flexible assessments in different modalities. They are advised to communicate with the learners' parents regarding the standards for assessment. For the monitoring, they are also encouraged to set up monitoring and recording through remote means. For the feedback, the order provides that teachers should give it in a timely, constructively, and relevant manner. In case that there are lagging students, remediation is also advised. These are some of the mandates for the teachers to be done during an alternative assessment; it requires effort and abrupt adjustments given the circumstance that we are in.

Alternative assessment, just like what the DepEd is implementing, has a variable, subjectivity. Subjectivity in assessment refers to information being gathered by the teacher based on a personal view, opinion, or value judgments (Courchenour and Chrisman, 2016) [12]. Teacher's subjectivity has a proven correlation to student's achievement. The study of Meissel, et al. (2017) [13], suggested that robust moderation of the judgment of the teachers is needed both with and between the schools. The same study suggests that professional development might help the teachers to make fair and consistent judgments. Teachers have judgments and expectations; both are affected by subjectivity (Ibid.) [13]. Expectations make the educators focus on expected performance over a future time (Ibid.) [13].

In the case of implementing the different learning modalities vis-à-vis distance learning, the distance between the teacher and the student is a variable; not mentioning the other external forces that would affect the teacher's assessment subjectivity. The fact that the new normal setting is a challenge to everybody, would likely make the educational community think that this is a "parausin na lang natin" matter.

A variety of challenges are in the way of the education system. Teachers, even though trained, are still having a hard time manipulating different tools in the new normal. This could develop the if-I-find-it-hard-my-students-willfind-it-hard-too philosophy. Students, on the other hand, lack the equipment needed to comply with the new normal; aside from lacking gadgets, students who can be contacted in the MDL or Modular Distance Learning through communication devices are insufficient. Hence, teachers are only to wait until the accomplished modules are submitted to their hands and to give the learners modules anew.

In the data gathered by the Department of Education through the SDOs' Research and Planning Unit [3], it revealed the following challenges: (1) $41 \%$ of 415,177 DepEd personnel are in favor of conducting classes online, through television or radio; and $66 \%$ of them also in favor of face-to-face classes with strict social distancing. This is despite the ownership of computers of 687,911 teachers of 787, 066 in the country; and 49\% of them have an internet connection. This only signifies that a challenge may be coming along the way.

With this, the medium where learning goes through and where evaluation crosses can be considered as the main variable in the teachers' standards of assessment. Medium, as defined by this study, is the pathway where the teachers and the students interact. In this study, it will be more focused on assessing the students' output.

To put the medium in a situation, consider this: a teacher asks his/ her student to make a video of his/ her speech and to be sent through a social media platform. 
When the teacher checked the speech output of the student, the video was blurry, and the sound was inaudible because the phone used to record the video was not a highend unit. Because of this, since the student complied considering that some were not able to do such considering the pandemic situation, the teacher has given his/ her a grade not lower than 90 .

Considering the dearth of resources as a problem of both the teachers and the students, and the more difficult coping mechanism of both parties towards the new normal, teachers put contemplation to this at a new level. The more challenging the educational situation, the more subjectivity is put into consideration; and this will affect the grading standards of the teacher.

In classroom management, consideration is needed to understand the learner. This is a recipe for a successful class session because the teachers will be able to know his/ her learner well thus establishing an effective teacherlearner relationship. However, putting more consideration heightens the teacher's subjectivity thus the purpose of assessment - objectivity - will be defeated. In a situation where few can comply, a huge amount of consideration should be given also in return for their effort.

In view to the situation that we have, a subjective attitude towards assessment is expected to be affected tremendously. Although teachers are to consider their students, adherence to the guidelines of proper assessment should still be followed.

All of these are just speculations and theoretical assumptions. Since teachers are mostly neophytes in the new normal framework of classes, this research targets to study the teachers' assessment practice in the new normal, their perception to the output of their students in the new normal, and how their assessment is affected by the new normal landscape of education specifically the medium used in assessing students' performance.

\section{STATEMENT OF THE PROBLEM}

This research primarily focuses on determining the subjectivity of teachers in assessing the students' output in the new normal.

To accomplish the main aim of this study, the research sought to answer the following questions:
(1) How may the profile of the respondents be described in terms of their:
a. age;
b. teaching position;
c. educational attainment;
d. grade level handled; and
e. district?

(2) How may the assessment practice of teacherrespondents be described in terms of:
a. frequency of checking.
b. medium of the output of the students;
c. assessment instrument; and
d. modality used?

(3) How do the teacher-respondents perceive the output of the students in the new normal in terms of its:
a. quality; and
b. acquired learning?

(4) How do the standards of the teacher's assessment are affected by the medium of the students' output in the new normal?

(5) Is there a significant relationship between the:

a. demographic profile of the respondents and;

i. their perception towards student's output in the new normal; and

ii. their standards in assessment?

b. perception towards student's output in the new normal and their standards in assessment?

\section{HYPOTHESES OF THE STUDY}

The study hypothesizes that there is no significant relationship among the following:

(1) Demographic profile of the respondents and:

a. their perception towards student's output in the new normal; and

b. their standards in assessment.

(2) Perception towards student's output in the new normal and their standards in assessment.

\section{RESEARCH PARADIGM}

The research follows the input process output framework to show the entire process of the study.

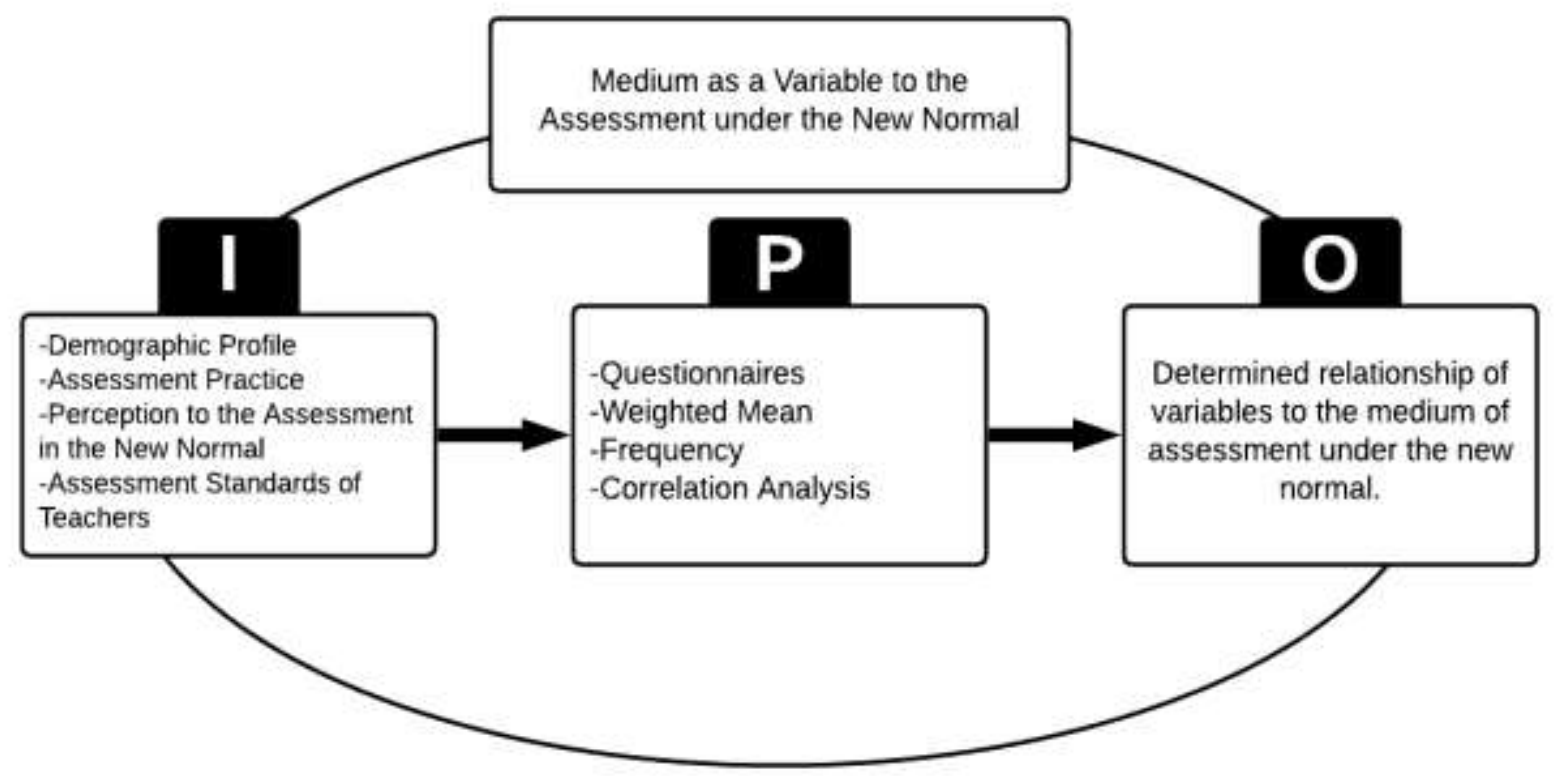

FIGURE 1: Research Paradigm 
This research focuses on determining whether the medium is a variable to the assessment of teachers under the new normal. To accomplish the research, the study gathered the demographic profile of the respondents, their assessment practice, and their perception of the assessment in the new normal.

To gather the necessary data, the researcher administered questionnaires to the respondents. The research instrument was a five-scale Likert questionnaire.

The data was processed using the necessary statistical tools for interpretation. After undergoing the interpretation process, the study would be able to determine whether the medium used in assessing students' output in the new normal has a relationship to the assessment of teachers.

\section{SIGNIFICANCE OF THE STUDY}

Despite the pandemic, learning should continue. As such, this is not just a response to mediocrely provide education per se but to deliver quality learning amidst the challenge of CoViD-19.

In relation, this research was realized since the Department of Education targets to deliver learning in new modes that most teachers are, at first, unfamiliar with to educate students in the safest way possible.

However, the effectiveness of a learning delivery cannot be determined by planning or by implementation alone. This can be measured through an evaluation. Hence, this research studied one of the areas in the new normal, assessment, and the subjective level of the teachers in the medium used in conducting such.

The findings of this study may be of great help to the following:

\section{DEPARTMENT OF EDUCATION}

As the central implementing body of the new delivery modes of learning in the new normal, the results of the study may help them see how the teachers perceive the medium used in assessment. The subjectivity - level of the teachers may give them an idea of the quality of assessment in the new normal.

\section{DIVISION OF NUEVA ECIJA}

As the locale where the research was conducted, the results may be used as the backbone of new policies in the division. Also, areas of improvement may be realized and data for strengths and weaknesses of its teachers regarding assessment may be identified and may be addressed if necessary.

\section{THE TEACHERS}

As the respondents of the study, the teachers may be able to view the picture of the quality of assessment in the new normal and how subjectivity affects their standards.

\section{FUTURE RESEARCHERS}

Since this research is a pioneering topic, the results of this research may be used in related topics such as distance learning, medium in assessment as a variable in assessment standards, assessment in case of emergency, and the likes.

\section{SCOPES AND LIMITATIONS OF THE STUDY}

The study will focus only on the parameters of the topic of this research - medium in assessing the outputs in the new normal as a variable in assessment standards. The researcher will gather the necessary data to attain the research questions thus accomplish the research's goal.
The instruments were given to the teachers of the Division of Nueva Ecija regardless of the grade level being handled. This helped the researcher to find out the involvement of

heterogeneous demographic profile to the overall response which were gathered in this study.

During the conduct of the research, the respondents were not given a time limit since the target of the research instruments was to measure and to determine their perception towards the medium being used in assessment on the new normal.

The data were processed using percentage, and weighted mean to process the demographic profile of the respondents. Spearman rank correlation was used as a tool in determining the relationship of (1) the demographic profile of the respondents and (A) their perception towards student's output in the new normal, and (B) their standards in assessment; and (2) their perception towards student's output in the new normal and their standards of assessment.

\section{METHODOLOGY \\ TYPE OF RESEARCH}

The research made use of mixed method design that is, a research method that involves qualitative and quantitative analysis (Fraenkel, 2013) [14]. A descriptive analysis is deemed to interpret the perception of teachers toward the new normal, their assessment practice, and demographic profile. Statistical tools through a correlation analysis will give light to the understanding of the relationship of the different variables in this research. Moreover, for further understanding of the data which will be gathered, the study will utilize constructed interviews for the respondents to give other comments or additions to what is found in the research instruments. This might help the researcher establish the assumed hypotheses of the study by understanding the "whys" of it. Hence, qualitative analysis will be needed for this.

\section{RESPONDENTS OF THE STUDY}

The study has chosen the teachers in the Department of Education - Division of Nueva Ecija, which, as of October 2020 , are 12,545 in number. Since the study sought to have only a particular number of respondents to serve as samples, the study used Slovin's sample size formula with $5 \%$ margin of error thus came up with a 373 number of samples (calculated with a 5\% margin of error and 95\% confidence level). Since the study is action research, it has purposely chosen the respondents for further study of findings thus a basis of the division's future undertakings for improvement as it monitors the standard of education being delivered to the students under the new normal.

\section{SAMPLING METHOD}

In a broad scope where there is a commonality of traits and are all involved in a policy yet there is no available exhaustive population list, the study made use of nonprobability sampling via convenience sampling method (CVENT, 2019) [15]. Convenience sampling is a nonprobability sampling method that collects data from a sample of the population who are available to be respondents of the study (research-methodology.net) [16]. The samples of the research are those who are conveniently available to participate in the study (Fraenkel, et al. 2013) [14].

This study did not establish any criteria except knowing the target respondents of the study - teachers in the Division of Nueva Ecija. The instruments will be distributed to those who are available to participate if they belong to the target population of the study. 


\section{CONCEPTUAL FRAMEWORK}

This research theoretically assumes that the more external challenges, the more subjective the teacher will be.

To arm the said assumption, this research took the sudden transition of the education landscape of the country as a variable because it has challenges along with it. This research tried to pioneer an instrument that would gauge the subjectivity level of the teachers amidst the challenges brought by the new normal. Several studies as cited by Meissel, et al. (2017) [13] revealed that the learners, for who they are, have a relationship to teachers' judgment Take Benner and Mistry (2007), Dompnier et al. (2006), Kaiser et al., (2013) as cited by Meissel, et al. (2017) [13], students' behavior affected the judgment of the teachers because boys tend to be problematic than of girls thus boys were often rated lower in academic or literacy skills. According to the literature review of the said journal behavioral factors such as student engagement and motivation influence teacher judgments.

However, these studies were conducted when the educational framework is designed "normally". Therefore, this study will try to determine how the challenge brought by the new normal specifically the medium used in assessment affects the teachers' subjectivity level in assessing students' performance.

With this, the data that this research provided would be much of great help to the policymakers of the education bureau - that assessment is not technical per se but is influenced by other variables including the teacher's subjectivity due to challenging situations.

\section{INSTRUMENTS OF THE STUDY}

The study aims to determine whether the medium being used in making the students' output is a variable in the assessment of the teachers. To attain this goal, the study made use of questionnaires that identify their demographic profile, their assessment practice, and their perception towards the output of students in the new normal. Their responses were measured using the five scale Likert Scale. Also, since this study is a pioneering study in the medium of assessment in the new normal, the research followed the validation and reliability testing procedures to ensure the instruments' quality.

\section{VALIDITY}

Since the research concerns the new normal of Department of Education, the researcher will seek the expertise of the SGOD - Planning and Research Office. The research instrument was based on the guidelines of Alternative Deliver Mode of the Department of Education through DepEd Memorandum 2020-00162, DepEd Order 31, s. 2020 and DepEd Order 8, s. 2015.

\section{RELIABILITY}

To identify the consistency of the research instruments which were utilized by the study, the study made use of Cronbach's Alpha in SPSS. This is utilized to measure internal consistency to know the internal consistency of the set of items as a group (Institute for Research and Education) [17]. Moreover, this is used to test whether the items in the test co-variate with one another.

The set of items in the five-scale-Likert Scale have undergone this test to ensure reliability. To conduct the reliability test, the researcher has used the test-retest method to measure the consistency of a test when given in the same sample at a different time (Middleton, 2020) [18]

\section{DATA COLLECTION PROCEDURE}

In this kind of study where perception towards a policy and how it becomes a variable in one's practice, a careful data collection method is advised. Thus, this research done the following to gather the necessary data needed.

The researcher sought the permission of the Schools Division Office of Nueva Ecija through SGOD - Planning and Research for the test administration. After the endorsement was given to the researcher, permission to conduct was sought to the same office.

In consideration of the pandemic, the instruments were conducted through an online survey form (Google Form). The links toward the questionnaire were given to respondents. After being given and the data were gathered afterward, the results were immediately processed using the statistical tools of the study.

\section{ETHICAL CONSIDERATION}

Ethics in research refers to what is right and wrong, placing the respondents' protection as a priority. Hence, careful procedure as the research being carried out should be given utmost importance (Fraenkel, 2012) [14]. In relation to this, the following were considered during the development of the research:

\section{RESPONDENTS}

The researcher informed the respondents regarding the study before letting them accomplish the questionnaires. They were not involved in the study by means of coercion but only by voluntary basis. Should any of their rights are violated, the researcher will take full responsibility of the respondents. Should anyone feel any discomfort, harm or danger, the respondents may refuse to participate in the study or withdraw their responses. After the respondents accomplished the research instruments, the researcher provided them information so that possible misconceptions will be avoided.

\section{DATA}

The data were processed and were not manipulated in favor to the research's hypothesis. All accomplished instruments were kept with confidentiality to safeguard the respondents' responses and information. The data were only for the research's use. Should any of the respondents feel to withdraw their responses, the researcher will return their responses. All raw data were not divulged in any way; only the processed data will be presented in the paper.

\section{DATA ANALYSIS}

The research data which were gathered were processed using the following statistical tools:

\section{WEIGHTED MEAN}

This was used to identify the average response of the respondents to the instruments. The formula for the weighted mean is as follows:

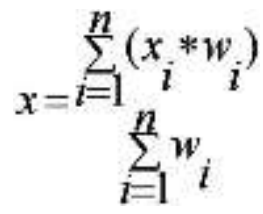

Where (Stephanie, 2020) [19]

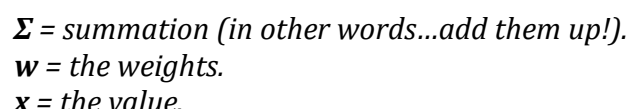

$\boldsymbol{x}=$ the value. 


\section{LIKERT SCALE}

The average responses were interpreted using a Likert Scale. The range of interpretation is as follows:

1.00 - 1.80 - Never/ Strongly Disagree

1.81 - 2.60 - Rarely/ Disagree

2.61 - 3.40 - Sometimes/ Somewhat Agree

3.41 - 4.20 - Often/ Agree

4.21 - 5.00 - Always/ Strongly Agree

\section{FREQUENCY}

This was used in processing the individual responses to the research instruments so also as the demographic profile of the respondents.

\section{SPEARMAN RANK CORRELATION}

This was used to determine the relationship of:

(1) the demographic profile of the respondents and (A) their perception towards student's output in the new normal, and (B) their standards in assessment; and

(2) their perception towards student's output in the new normal and their standards of assessment.

\section{RESULTS AND DISCUSSION}

This part presents the results and discussion of the study. This contains the data which were gathered through the research instruments designed to gather the necessary data to attain the objective of this study - to determine whether the medium of assessment and the teachers perception influence their standards in assessment.

Presented here in this section are demographic profile of the respondents, their assessment practice, their perception to the students' output, and their standards in assessing the output of the students in the new normal.

\section{DEMOGRAPHIC PROFILE OF THE RESPONDENTS}

- Age

TABLE 1: Age of the Respondents

\begin{tabular}{|c|c|c|}
\hline Ages & $\mathbf{N}$ & $\mathbf{\%}$ \\
\hline $\mathbf{2 1}-\mathbf{3 0}$ & 129 & $32.4 \%$ \\
\hline $\mathbf{3 1}-\mathbf{4 0}$ & 146 & $36.7 \%$ \\
\hline $\mathbf{4 1}-\mathbf{5 0}$ & 87 & $21.9 \%$ \\
\hline $\mathbf{5 1}-\mathbf{6 0}$ & 36 & $9 \%$ \\
\hline $\mathbf{6 1}$ and Above & 0 & $100 \%$ \\
\hline
\end{tabular}

Based on the table above, most of the teacher - respondents age is ranging from $31-40(36.7 \%)$ and $21-30$ (32.4\%). $21.9 \%$ of the respondents have an age ranging from $41-50$ years old. $9 \%$ are $51-60 \%$ years old.

This means that most respondents are between the age of $21-40$. However, the age of the teacher is not considered a barrier to teaching (Shah and Udgaonkar, 2018) [21].

\section{- Teaching Position}

TABLE 2: Designation of the Respondents

\begin{tabular}{|c|c|c|}
\hline Teaching Position & $\mathbf{N}$ & $\%$ \\
\hline Teacher I & 128 & $32 \%$ \\
\hline Teacher II & 37 & $9 \%$ \\
\hline Teacher III & 193 & $48.5 \%$ \\
\hline Master Teacher I & 30 & $7.5 \%$ \\
\hline Master Teacher II & 6 & $1.5 \%$ \\
\hline Master Teacher III & 4 & $1.00 \%$ \\
\hline Master Teacher IV & 0 & $0 \%$ \\
\hline Total & 398 & $100 \%$ \\
\hline
\end{tabular}

As indicated in the table, $48.5 \%$ of the teacher respondents are Teacher III and 32\% of them are Teacher I. $9 \%$ are Teacher II, 7.5\% are Master Teacher I, 1.5\% are Master Teacher II, and $1.00 \%$ are Master Teacher III.

The teacher's promotion is an indication of their experience. Thus, grading and handling students are enhanced as they grow in the profession. According to Wayne and Young (2003) [20], teacher's experience and student achievement shows a positive relationship.

According to the Evaluation Record Form, for one to be a teacher III, s/he must have completed academic requirements remark or at least have a year of experience. The number of Teacher I respondents also can be an indication of the studies' scattered characteristics of the respondents thus, homogeneity of responses will be avoided in terms of perception.

\section{- Highest Educational Attainment}

TABLE 3: Highest Educational Attainment of the Respondents

\begin{tabular}{|l|c|c|}
\hline Educational Attainment & $\mathbf{N}$ & $\mathbf{\%}$ \\
\hline Bachelor's Degree & 313 & $78.64 \%$ \\
\hline Master's Degree & 80 & $20.10 \%$ \\
\hline Doctorate Program & 5 & $1.26 \%$ \\
\hline
\end{tabular}

In terms of the teacher - respondents' highest educational attainment, majority of the teacher - respondents are bachelor's degree graduate with a percentage of $78.64 \%$. $20.10 \%$ are master's degree, and $1.26 \%$ are doctorate graduate.

\section{- Grade Level Being Handled}

TABLE 4: Grade Level being Handled by the Respondents

\begin{tabular}{|l|c|c|}
\hline Grade Level Being Taught & N & \% \\
\hline Kindergarten & 48 & $12 \%$ \\
\hline Elementary & 243 & $61.05 \%$ \\
\hline Junior High School & 86 & $21.60 \%$ \\
\hline $\begin{array}{l}\text { Junior High School and } \\
\text { Senior High School }\end{array}$ & 1 & $0.25 \%$ \\
\hline Senior High School & 20 & $5.03 \%$ \\
\hline
\end{tabular}

In terms of the respondents' grade level being handled, $61.05 \%$ of the respondents are elementary, $21.60 \%$ are junior high school, $12 \%$ are kindergarten, $5.03 \%$ are senior high school, and $0.25 \%$ for integrated junior high school and senior high school.

\section{- Handling Special Programs}

TABLE 5: Programs being Handled by the Respondents

\begin{tabular}{|c|c|c|}
\hline $\begin{array}{c}\text { Do they handle special } \\
\text { programs? }\end{array}$ & $\mathbf{N}$ & $\mathbf{\%}$ \\
\hline Yes & 94 & $23.62 \%$ \\
\hline No & 304 & $76.38 \%$ \\
\hline
\end{tabular}

$76.38 \%$ of the teacher - respondents are not handling special programs. Only $23.62 \%$ are handling special programs. 
- District

TABLE 6: SDO Annexes of the Respondents

\begin{tabular}{|l|c|c|}
\hline \multicolumn{1}{|c|}{ SDO - Annex } & N & \% \\
\hline Aliaga & 36 & $9.05 \%$ \\
\hline Bongabon & 18 & $4.52 \%$ \\
\hline Cabiao & 73 & $18.34 \%$ \\
\hline Caranglan & 3 & $0.75 \%$ \\
\hline Cuyapo East & 26 & $6.53 \%$ \\
\hline Cuyapo West & 34 & $8.54 \%$ \\
\hline Gen. Natividad & 8 & $2.01 \%$ \\
\hline Gen. Tinio & 1 & $0.25 \%$ \\
\hline Guimba East & 2 & $0.50 \%$ \\
\hline Guimba West & 1 & $0.25 \%$ \\
\hline Jaen North & 44 & $11.05 \%$ \\
\hline Llanera & 1 & $0.25 \%$ \\
\hline Lupao & 1 & $0.25 \%$ \\
\hline Nampicuan & 48 & $12.06 \%$ \\
\hline Palayan & 2 & $0.50 \%$ \\
\hline Pantabangan & 27 & $6.78 \%$ \\
\hline Rizal & 27 & $6.78 \%$ \\
\hline San Antonio & 2 & $0.50 \%$ \\
\hline San Leonardo & 9 & $2.26 \%$ \\
\hline Santa Rosa South & 1 & $0.25 \%$ \\
\hline Sto. Domingo & 3 & $0.75 \%$ \\
\hline Zaragoza & 31 & $7.79 \%$ \\
\hline
\end{tabular}

ASSESSMENT PRACTICES OF TEACHER RESPONDENTS FREQUENCY OF CHECKING

\begin{tabular}{|l|c|c|}
\hline \multicolumn{1}{|c|}{ Frequency of Checking } & $\mathbf{N}$ & $\mathbf{\%}$ \\
\hline Never & 0 & $0 \%$ \\
\hline Once a week & 167 & $41.96 \%$ \\
\hline Twice a week & 79 & $19.85 \%$ \\
\hline Thrice a week & 65 & $16.33 \%$ \\
\hline Four times a week & 29 & $7.29 \%$ \\
\hline Everyday & 50 & $12.56 \%$ \\
\hline Scheduled every month & 7 & $1.76 \%$ \\
\hline At the end of the quarter & 0 & $0 \%$ \\
\hline
\end{tabular}

$41.96 \%$ of the teacher - respondents check the outputs of their students once a week. $19.85 \%$ twice a week and $16.33 \%$ of them check the output of the students thrice a week.

The checking of the outputs of the students is influenced by the other tasks that they do such as distribution and retrieval of materials, remote teaching, and other tasks.

In further analyzing the results of the study, it was found out that there was a perfect correlation of the teacher's age $(p$ value $=.000)$ and designation $(p$ value $=.000)$ to their frequency of checking.

TABLE 7: Hours of Checking

\begin{tabular}{|l|c|c|}
\hline $\begin{array}{c}\text { If per week, how many } \\
\text { hours? }\end{array}$ & $\mathbf{N}$ & $\mathbf{\%}$ \\
\hline Less than an hour & 14 & $3.59 \%$ \\
\hline $\mathbf{1}$ - 2 hours & 131 & $33.59 \%$ \\
\hline 3 - 4 hours & 173 & $44.36 \%$ \\
\hline 5 - 6 hours & 57 & $14.62 \%$ \\
\hline More than 7 hours & 15 & $3.85 \%$ \\
\hline
\end{tabular}

The teacher - respondents who are checking the output of the students weekly, $44.36 \%$ spend $3-4$ hours of checking and $33.59 \%$ an hour to two. $14.62 \%$ of them spend $5-6$ hours in checking, 3.56\% spend less than an hour and the remaining $3.85 \%$ spend more than 7 hours checking.

Most respondents spend $1-4$ hours checking. This is because of the spacious time that they are having. One reason for this is that classes are not that time-consuming to conduct. Usually, they give instructions and assistance to the students which only take about 30 minutes to 1 hour. This usually occurs on printed modular distance learning.

\section{- Medium of the Output of the Students}

TABLE 8: Medium of the Output of the Students

\begin{tabular}{|c|c|c|}
\hline Forms of Students Output & $\mathbf{N}$ & $\%$ \\
\hline $\begin{array}{l}\text { Hardcopies/printed } \\
\text { copies }\end{array}$ & 386 & $96.98 \%$ \\
\hline Chats/ Group Chats & 211 & $53.02 \%$ \\
\hline Text messages & 107 & $26.88 \%$ \\
\hline Mobile Calls & 71 & $17.84 \%$ \\
\hline Video calls in messenger & 54 & $13.58 \%$ \\
\hline $\begin{array}{l}\text { Video conferences via } \\
\text { Zoom, Google Meet, MS } \\
\text { Teams, and the likes }\end{array}$ & 40 & $10.05 \%$ \\
\hline $\begin{array}{l}\text { Video uploads in social } \\
\text { media sites. }\end{array}$ & 37 & $9.3 \%$ \\
\hline $\begin{array}{l}\text { Online forms such as } \\
\text { Google Forms, MS Forms }\end{array}$ & 31 & $7.79 \%$ \\
\hline $\begin{array}{l}\text { Learning Management } \\
\text { System using Google } \\
\text { Classroom, Schoology, } \\
\text { Edmodo, etc. }\end{array}$ & 23 & $5.78 \%$ \\
\hline Email & 17 & $4.27 \%$ \\
\hline $\begin{array}{l}\text { Outputs via cloud storage } \\
\text { (e.g., Google Drive, One } \\
\text { Drive) }\end{array}$ & 15 & $3.77 \%$ \\
\hline $\begin{array}{l}\text { Comments in a social } \\
\text { media post }\end{array}$ & 9 & $2.26 \%$ \\
\hline $\begin{array}{l}\text { Reactions (e.g., like, love, } \\
\text { haha) in a social media } \\
\text { post }\end{array}$ & 8 & $2.01 \%$ \\
\hline $\begin{array}{l}\text { Live videos in social } \\
\text { media sites. }\end{array}$ & 4 & $1 \%$ \\
\hline $\begin{array}{l}\text { Others* } \\
\text { *Book Widgets and } \\
\text { Edulastic } \\
\end{array}$ & 3 & $0.75 \%$ \\
\hline
\end{tabular}

Based on the table, most of the teacher - respondents prefer or use hardcopies or printed copies as the form of the students' output with a percentage of $96.98 \%$. Half of the respondents, $53.02 \%$, prefer chats; $26.88 \%$, text messages; $17.84 \%$, mobile calls and $13.58 \%$, video calls in Facebook Messenger. The least medium used by the teachers in assessing their students are Live Videos, Facebook reactions (e.g., like, love, haha) and comments.

It can be observed from the data that the students' form of outputs is accessible to them such as hardcopies, chats, text messages, mobile calls and video calls. Due to the dearth of equipment at home, parents prefer printed copies and hardcopy of outputs. Aside from that, students have social media accounts that are accessible to most people due to the free data-promos of some mobile networks.

Because of this, the teachers adjust to the preferences of the parents and students. This is in accordance to the DO 31 , s. 2020 that states that teachers should make assessment flexible in different learning modalities. 
Through a correlation bivariate analysis between: the age, designation, kind of program being handled, educational attainment, and grade level being handled have a relationship with the medium being used in assessing the students ( $p=$ value $\geq 0.01$ or 0.05 level of significance).

\section{- Assessment Instruments}

TABLE 9: Assessment Instruments

\begin{tabular}{|c|c|c|}
\hline Assessment Instruments & $\mathbf{N}$ & $\%$ \\
\hline Multiple Choice & 284 & $71.36 \%$ \\
\hline True or False & 208 & $52.26 \%$ \\
\hline Matching Items & 195 & $48.99 \%$ \\
\hline Essay & 172 & $43.22 \%$ \\
\hline Filling of Blanks & 159 & $39.95 \%$ \\
\hline Enumeration & 116 & $29.15 \%$ \\
\hline Portfolios & 112 & $28.14 \%$ \\
\hline Poster making & 79 & $19.85 \%$ \\
\hline Art projects & 71 & $17.83 \%$ \\
\hline Storytelling/ reading & 46 & $11.56 \%$ \\
\hline Reaction/ reflection papers & 39 & $9.8 \%$ \\
\hline Collages & 35 & $8.79 \%$ \\
\hline Story/ Poem Writing & 34 & $8.54 \%$ \\
\hline Data recording & 31 & $7.79 \%$ \\
\hline Interview & 30 & $7.54 \%$ \\
\hline Compositions & 28 & $7.03 \%$ \\
\hline Models and Diagrams & 26 & $6.53 \%$ \\
\hline Demonstration & 25 & $6.28 \%$ \\
\hline Design and Layout & 22 & $5.53 \%$ \\
\hline Concept Maps & 20 & $5.02 \%$ \\
\hline Physical Activity Participation & 20 & $5.02 \%$ \\
\hline Personalized Exercise & 18 & $4.52 \%$ \\
\hline Journals & 17 & $4.27 \%$ \\
\hline Book/ Article reviews & 14 & $3.52 \%$ \\
\hline Multimedia Presentations & 14 & $3.52 \%$ \\
\hline Surveys & 12 & $3.02 \%$ \\
\hline $\begin{array}{l}\text { Laboratory reports and } \\
\text { documentations }\end{array}$ & 11 & $2.76 \%$ \\
\hline Multimedia Productions & 11 & $2.76 \%$ \\
\hline Reports & 10 & $2.51 \%$ \\
\hline Art exhibit & 9 & $2.26 \%$ \\
\hline Research Projects & 9 & $2.26 \%$ \\
\hline Role plays & 9 & $2.26 \%$ \\
\hline Awareness campaigns & 8 & $2.01 \%$ \\
\hline Documentary/ film review & 8 & $2.01 \%$ \\
\hline Community Involvement & 7 & $1.76 \%$ \\
\hline Literary Analyses & 7 & $1.76 \%$ \\
\hline Speech Delivery & 7 & $1.76 \%$ \\
\hline Scientific Investigations & 6 & $1.51 \%$ \\
\hline Song Analysis & 5 & $1.26 \%$ \\
\hline Timelines & 5 & $1.26 \%$ \\
\hline Others & 5 & $1.26 \%$ \\
\hline Investigatory projects & 4 & $1.01 \%$ \\
\hline Musical Arrangements & 4 & $1 \%$ \\
\hline Campaigns & 3 & $0.75 \%$ \\
\hline Map Construction & 3 & $0.75 \%$ \\
\hline
\end{tabular}

\begin{tabular}{|l|c|c|}
\hline News writing & 3 & $0.75 \%$ \\
\hline $\begin{array}{l}\text { Personal fitness and health } \\
\text { logs }\end{array}$ & 3 & $0.75 \%$ \\
\hline Simulation & 3 & $0.75 \%$ \\
\hline $\begin{array}{l}\text { Diagnosis and repair of } \\
\text { damaged equipment. }\end{array}$ & 2 & $0.5 \%$ \\
\hline News reporting & 2 & $0.5 \%$ \\
\hline Panel Discussions & 2 & $0.5 \%$ \\
\hline Case Studies & 1 & $0.25 \%$ \\
\hline $\begin{array}{l}\text { Designing and } \\
\text { Planplementation of Action }\end{array}$ & 1 & $0.25 \%$ \\
\hline Prototype building & 1 & $0.25 \%$ \\
\hline Debates & 0 & $0 \%$ \\
\hline
\end{tabular}

For the assessment instruments being used by the teachers, $71.36 \%$ of the respondents prefer multiple choice item test; $52.26 \%$ prefer True or False; $48.99 \%$ prefer Matching Type; $43.22 \%$ prefer Essay; $39.95 \%$ prefer Filling of Blanks; and $29.15 \%$ prefer Enumeration.

The results are congruent to the preference of the parents and students - hardcopies. Multiple choices, true or false, matching type, essay, filling in the blanks, and enumeration are usually found in hardcopies. Aside from being accessible to all, these types of assessment are convenient to be checked whether it may be online or through hardcopies.

\section{- Modality Used}

TABLE 10: Modality Being Used in Assessing the Students

\begin{tabular}{|l|c|c|}
\hline \multicolumn{1}{|c|}{ Modality Being Used } & N & \% \\
\hline $\begin{array}{l}\text { Submitted by the parents/ } \\
\text { guardians to the school }\end{array}$ & 306 & $76.88 \%$ \\
\hline Both & 88 & $22.11 \%$ \\
\hline Online & 4 & $1.01 \%$ \\
\hline
\end{tabular}

In terms of the modality that is being used by the respondents in assessing their students, majority of them, $76.88 \%$, prefer the outputs to be submitted by the parents during the distribution and retrieval of the modules and learning activity sheets. $22.11 \%$ of the respondents do blended modalities and only $1.01 \%$ of them assess their students online.

Their preference of assessment is based on the data of the students in terms of their available resources at home (gathered thru LESF). The way of submitting the output of the students is based on their chosen learning modality.

\section{PERCEPTION OF TEACHERS ON THE OUTPUT OF THE STUDENTS IN THE NEW NORMAL}

\section{- Quality}

TABLE 11: Perception on the Output of the Students in the New Normal

\begin{tabular}{|l|c|c|}
\hline \multicolumn{1}{|c|}{ Statement } & $\begin{array}{c}\text { Weighted } \\
\text { Mean }\end{array}$ & $\begin{array}{c}\text { Verbal } \\
\text { Interpretation }\end{array}$ \\
\hline $\begin{array}{l}\text { The output before is } \\
\text { better than of the } \\
\text { new normal } \\
\text { landscape of } \\
\text { education. }\end{array}$ & 4.03 & Agree \\
\hline
\end{tabular}




\begin{tabular}{|l|c|c|}
\hline $\begin{array}{l}\text { Parents help their } \\
\text { children in accomplishing } \\
\text { the output thus the } \\
\text { students become better. }\end{array}$ & 3.94 & Agree \\
\hline $\begin{array}{l}\text { The output of the students } \\
\text { is of good quality in terms } \\
\text { of its content. }\end{array}$ & 3.87 & Agree \\
\hline $\begin{array}{l}\text { The students give their } \\
\text { best shot as they } \\
\text { accomplish the outputs in } \\
\text { my activities. }\end{array}$ & 3.84 & Agree \\
\hline $\begin{array}{l}\text { The student's output's } \\
\text { appearance is of good } \\
\text { quality (e.g., clear, not } \\
\text { blurry, clearly shot, etc.) }\end{array}$ & 3.82 & Agree \\
\hline $\begin{array}{l}\text { The student's diligence is } \\
\text { evident to their output. }\end{array}$ & 3.79 & Agree \\
\hline $\begin{array}{l}\text { Students spend much to } \\
\text { comply with the outputs. }\end{array}$ & 3.54 & Agree \\
\hline $\begin{array}{l}\text { The students' output is for } \\
\text { compliance alone. }\end{array}$ & 3.47 & Agree \\
\hline $\begin{array}{l}\text { The parents are the ones } \\
\text { who accomplish the } \\
\text { output of the students. }\end{array}$ & 3.46 & Agree \\
\hline $\begin{array}{l}\text { Students enhanced their } \\
\text { output because of the } \\
\text { distance learning. }\end{array}$ & 3.46 & Agree \\
\hline $\begin{array}{l}\text { The outputs are free from } \\
\text { context and grammatical } \\
\text { errors. }\end{array}$ & 3.28 & Agree \\
\hline $\begin{array}{l}\text { The output of the students } \\
\text { fn the new normal are safe } \\
\text { from plagiarism. }\end{array}$ & 3.26 & Somewhat \\
\hline
\end{tabular}

Above is the table that presents the perception of teachers on the output of the students in the new normal. Below are the findings of the study regarding the problem:

The respondents agree (4.03) that the output of the before, when there was no pandemic is better than the outputs in the new normal. According to the teachers, face-to-face learning helps them evaluate the learner's performance through observation. F2F give them indicators whether the child understand the lesson or not.

The teacher - respondents agree (3.94) that the parents of their children in accomplishing the output. This makes the students become better.

They agree (3.87) that the content of the students' output is of good quality. The explanation for this can be seen on their perception (3.84) that the students do their best when accomplishing the outputs in their activities.

In terms of the appearance of the output of the students, the teacher - respondents agree (3.82) that they are of good quality. They agree (3.79) that from the output of the students, their diligence can be easily seen. Since the learning materials of the students can be accomplished by just responding to activities and vacate those that are difficult, the teachers can easily see who exerted an effort for a particular learning episode.
The teachers themselves, agree (3.54) that the students spend much to comply with the outputs. This is because they see the number of activities that the students need to comply.

They agree (3.47) that the output of the students is for compliance alone. This is due to the number of retrieved papers that only those activities that require responses were the ones answered by the students.

The teachers agree (3.46) that the parents of their students are the ones who accomplish the outputs of the students. The same weighted mean was gotten by the statement, "the students enhanced their output because of distance learning".

The teachers somewhat agree (3.28) that the outputs of the students are free from grammatical errors.

They also somewhat agree (3.26) that the outputs of the students are safe from plagiarism. According to the respondents, since internat is more accessible to day, students tend to copy and paste their answers. They also shared their analyzing techniques for plagiarism. When they notice that there is a change in the style of writing of the students, they assume that the students have plagiarized their work.

\section{- Acquired Learning}

Table 12: Perceptions on the Acquired Learning from the Output in the New Normal

\begin{tabular}{|l|c|c|}
\hline \multicolumn{1}{|c|}{ Statement } & $\begin{array}{c}\text { Weighted } \\
\text { Mean }\end{array}$ & $\begin{array}{c}\text { Verbal } \\
\text { Interpretation }\end{array}$ \\
\hline $\begin{array}{l}\text { The teacher can easily } \\
\text { identify whether s/he } \\
\text { attained his / her set } \\
\text { objectives by checking } \\
\text { the output of the } \\
\text { students. }\end{array}$ & 3.69 & Agree \\
\hline $\begin{array}{l}\text { The learners can } \\
\text { transfer their learning } \\
\text { concepts to real life } \\
\text { situations. This can be } \\
\text { seen in their outputs } \\
\text { in the new normal. }\end{array}$ & 3.65 & Agree \\
\hline $\begin{array}{l}\text { Discovery learning is } \\
\text { evident in DL outputs. }\end{array}$ & 3.64 & Agree \\
\hline $\begin{array}{l}\text { Learners learn } 21 \text { st } \\
\text { century skills in } \\
\text { distance learning. }\end{array}$ & 3.63 & Agree \\
\hline $\begin{array}{l}\text { The students' } \\
\text { creativity can be } \\
\text { showcased in DL } \\
\text { outputs. }\end{array}$ & 3.62 & Agree \\
\hline $\begin{array}{l}\text { The critical thinking of } \\
\text { students can be } \\
\text { evidently seen in their } \\
\text { outputs. }\end{array}$ & 3.52 & Agree \\
\hline $\begin{array}{l}\text { The outputs of the } \\
\text { students in the new } \\
\text { normal can easily tell } \\
\text { the teachers whether } \\
\text { the students acquired } \\
\text { cognitive, } \\
\text { psychomotor, and } \\
\text { effective skills or not. }\end{array}$ & 3.51 & \\
\hline
\end{tabular}




\begin{tabular}{|l|c|c|}
\hline $\begin{array}{l}\text { The learner develops } \\
\text { ICT skills more than } \\
\text { content skills. }\end{array}$ & 3.45 & Agree \\
\hline $\begin{array}{l}\text { It is easy to assess the } \\
\text { students' output in the } \\
\text { new normal. }\end{array}$ & 3.17 & $\begin{array}{l}\text { Somewhat } \\
\text { Agree }\end{array}$ \\
\hline
\end{tabular}

The table above presents the perception of the teachers in terms of the acquired learning of the students in distance learning

The teachers agree (3.69) that they can easily identify whether the students have attained his/ her set objectives by checking the outputs of the students. Also, with the outputs of the students, the teacher agrees (3.65) that the learners can transfer their learning concepts to real life situation.

They agree (3.64) that discovery learning can be evidently seen on the output of the students. They assess this by asking the students to send videos and outputs that reflect their discovery. Moreover, the construction of the learning materials is aligned to discovery learning.

The teachers agree (3.63) that even though the learners are engaged in a distance learning setup, the students learn $21^{\text {st }}$ century skills. This is because the students learn to utilize ICT tools, communication skills and independent learning.

The teachers agree (3.62) that student's creativity can be showcased in distance learning output.

In terms of critical thinking, the teachers agree (3.52) that it can be evidently seen in the student's outputs.

They agree (3.51) that the outputs of the students can easily help them determine whether the students acquired cognitive, psychomotor, and effective skills or not.

They agree (3.45) that the learners develop ICT skills more than content skills.

The teachers somewhat agree (3.17) that it is easy to assess the students' output in the new normal.

\section{STANDARDS OF THE TEACHER IN ASSESSING THE} OUTPUT OF THE STUDENTS IN THE NEW NORMAL

- Medium as a Variable in Assessment

TABLE 13: Perceived Standards of the Teachers in Assessing the Output of the Students in the New Normal

\begin{tabular}{|l|c|c|}
\hline \multicolumn{1}{|c|}{ Statement } & $\begin{array}{c}\text { Weighted } \\
\text { Mean }\end{array}$ & $\begin{array}{c}\text { Verbal } \\
\text { Interpretation }\end{array}$ \\
\hline $\begin{array}{l}\text { When an output is in a } \\
\text { hardcopy (e.g., modules, }\end{array}$ & & \\
$\begin{array}{l}\text { LAS, etc.), It should be } \\
\text { checked more carefully } \\
\text { than softcopies (i.e., } \\
\text { videos, digital modules/ }\end{array}$ & 3.87 & Agree \\
LAS, etc.). & & \\
\hline $\begin{array}{l}\text { There should be a } \\
\text { minimum value on } \\
\text { down to what } \\
\text { particular grade a } \\
\text { student may have (For } \\
\text { instance, all students } \\
\text { will not have a grade } \\
\text { lower than 70) in the } \\
\text { outputs on the new } \\
\text { normal. }\end{array}$ & 3.84 & Agree \\
\hline
\end{tabular}

\begin{tabular}{|l|l|l|}
\hline $\begin{array}{l}\text { No student who has } \\
\text { submitted his/ her } \\
\text { output in the new } \\
\text { normal should have a } \\
\text { failing grade. }\end{array}$ & 3.74 & Agree \\
\hline $\begin{array}{l}\text { There should be a } \\
\text { maximum grade limit } \\
\text { to students today (For } \\
\text { instance, all students } \\
\text { may have a grade not } \\
\text { higher that 95) on the } \\
\text { outputs of the new } \\
\text { normal. }\end{array}$ & 3.68 & Agree \\
\hline $\begin{array}{l}\text { There are times that } \\
\text { teachers should not } \\
\text { only rely on rubrics in } \\
\text { checking the outputs of } \\
\text { the students in the new } \\
\text { normal. }\end{array}$ & 3.68 & Agree \\
\hline $\begin{array}{l}\text { The standard in } \\
\text { checking the outputs in } \\
\text { the new normal should } \\
\text { be more on effort than } \\
\text { the content. }\end{array}$ & 3.66 & Agree \\
\hline $\begin{array}{l}\text { When a student } \\
\text { submitted his/ her } \\
\text { output, there is } \\
\text { automatically a grade } \\
\text { regardless of the } \\
\text { content. }\end{array}$ & 3.65 & Agree \\
\hline $\begin{array}{l}\text { Subjectivity is more } \\
\text { important today than } \\
\text { being objective in } \\
\text { checking the output in } \\
\text { the new normal. }\end{array}$ & 3.25 & \\
\hline $\begin{array}{l}\text { An output in the new } \\
\text { normal should not be } \\
\text { returned to the } \\
\text { students if it is } \\
\text { incorrect. They should } \\
\text { be given a grade } \\
\text { instead. }\end{array}$ & & \\
\hline
\end{tabular}

The table above present the response of the teacher respondents on the medium as a variable in assessment.

The respondents agree (3.87) that when an output is in a hardcopy, it should be checked more carefully than softcopies.

The teachers agree (3.84) that there should be a minimum value on down to what particular grade a student may have (e.g., all students will not have a grade lower than 70) in the outputs on the new normal.

The agree (3.74) that no students who has submitted his/ her output in the new normal should have a failing grade.

They agree (3.68) that there should be a maximum grade limit to the students' today (e.g., students may have a grade but not higher than 95) on the outputs of the new normal.

The teachers agree (3.68) that there are times that they should not only rely on rubrics in checking the outputs in the new normal.

They agree (3.66) that the standard of checking should focus more on effort that the content 
They agree (3.65) that when a student submitted his/ her output, there should be an automatic grade.

They agree (3.65) that subjectivity is more important in distance learning than being objective in checking the output of the students.

\section{RELATIONSHIP BETWEEN DEMOGRAPHIC PROFILE OF THE RESPONDENTS AND PERCEPTION TOWARDS THE OUTPUT OF THE STUDENTS IN THE NEW NORMAL}

- Quality

TABLE 13: Correlation Table for the Profile of the Respondents and them Perceptions towards the Quality of Output of the Students

\begin{tabular}{|c|c|c|c|c|c|c|c|c|c|c|c|c|c|c|}
\hline & $\begin{array}{c}\text { Quality } \\
1\end{array}$ & $\begin{array}{c}\text { Quality } \\
2\end{array}$ & $\begin{array}{c}\text { Quality } \\
3\end{array}$ & $\begin{array}{c}\text { Quality } \\
4\end{array}$ & $\begin{array}{c}\text { Quality } \\
5\end{array}$ & $\begin{array}{c}\text { Quality } \\
6\end{array}$ & $\begin{array}{c}\text { Quality } \\
7\end{array}$ & $\begin{array}{c}\text { Quality } \\
8\end{array}$ & $\begin{array}{c}\text { Quality } \\
9\end{array}$ & $\begin{array}{c}\text { Quality } \\
10\end{array}$ & $\begin{array}{c}\text { Quality } \\
11\end{array}$ & $\begin{array}{c}\text { Quality } \\
12\end{array}$ \\
\hline \multirow{10}{*}{$\begin{array}{c}\text { Spearman's } \\
\text { rho }\end{array}$} & \multirow[t]{2}{*}{$\begin{array}{l}\text { DP Educa- } \\
\text { tional } \\
\text { Attain }\end{array}$} & $\begin{array}{l}\text { Corre- } \\
\text { lation } \\
\text { Coeffi- } \\
\text { cient }\end{array}$ & -.076 & -.042 & -.048 & .002 & -.074 & .010 & -.004 & -.009 & -.037 & -.036 & -.038 & -.024 \\
\hline & & $\begin{array}{l}\text { Sig. (2- } \\
\text { tailed) }\end{array}$ & .130 & .407 & .343 & .964 & .140 & .847 & .944 & .859 & .465 & .477 & .452 & .639 \\
\hline & \multirow[t]{2}{*}{$\begin{array}{l}\text { DP Desig- } \\
\text { nation }\end{array}$} & $\begin{array}{l}\text { Corre- } \\
\text { lation } \\
\text { Coeffi- } \\
\text { cient }\end{array}$ & -.046 & -.012 & -.019 & .004 & $.111^{*}$ & -.006 & -.053 & -.008 & -.070 & -.009 & -.036 & -.035 \\
\hline & & $\begin{array}{l}\text { Sig. (2- } \\
\text { tailed) }\end{array}$ & .362 & .810 & .701 & .931 & .027 & .898 & .289 & .878 & .163 & .859 & .478 & .491 \\
\hline & \multirow[t]{2}{*}{ DP Age } & $\begin{array}{l}\text { Corre- } \\
\text { lation } \\
\text { Coeffi- } \\
\text { cient }\end{array}$ & -.075 & -.045 & -.024 & .020 & $.124^{*}$ & .007 & -.064 & -.017 & -.082 & -.027 & -.051 & -.065 \\
\hline & & $\begin{array}{l}\text { Sig. (2- } \\
\text { tailed) }\end{array}$ & .135 & .372 & .630 & .693 & .013 & .894 & .200 & .741 & .102 & .589 & .307 & .195 \\
\hline & \multirow{2}{*}{$\begin{array}{l}\text { DP Grade } \\
\text { Level } \\
\text { Being } \\
\text { Handled }\end{array}$} & $\begin{array}{l}\text { Corre- } \\
\text { lation } \\
\text { Coeffi- } \\
\text { cient }\end{array}$ & -.045 & -.031 & -.041 & .023 & -.092 & .048 & .002 & .007 & -.036 & -.044 & -.010 & .002 \\
\hline & & $\begin{array}{l}\text { Sig. (2- } \\
\text { tailed) }\end{array}$ & .367 & .531 & .410 & .648 & .067 & .341 & .967 & .883 & .478 & .383 & .841 & .964 \\
\hline & \multirow[t]{2}{*}{$\begin{array}{l}\text { DP } \\
\text { Special } \\
\text { Subjects }\end{array}$} & $\begin{array}{l}\text { Correla } \\
\text { tion } \\
\text { Coeffici } \\
\text { ent }\end{array}$ & -.038 & -.010 & .011 & .036 & -.066 & .059 & -.065 & .003 & -.013 & -.018 & -.025 & -.018 \\
\hline & & $\begin{array}{l}\text { Sig. (2- } \\
\text { tailed) }\end{array}$ & .446 & .846 & .829 & .476 & . 186 & .242 & .195 & .950 & .798 & .715 & .626 & .715 \\
\hline
\end{tabular}

Based on the table above, the following have significant relationship because $\mathrm{p} \leq 0.05$ or 0.01 : Designation and age and statement 5 in the perception of the teachers in terms of quality, "The students give their best shot as they accomplish the outputs in my activities."
They somewhat agree (3.25) that an output in the new normal should not be returned to the students if it is incorrect. The students should be given a grade instead. 


\section{- Acquired Learning}

TABLE 14: Correlation Table for the Profile of the Respondents and their Perceptions towards Acquired Learning vis - a - vis the Assessment of Output of the Students

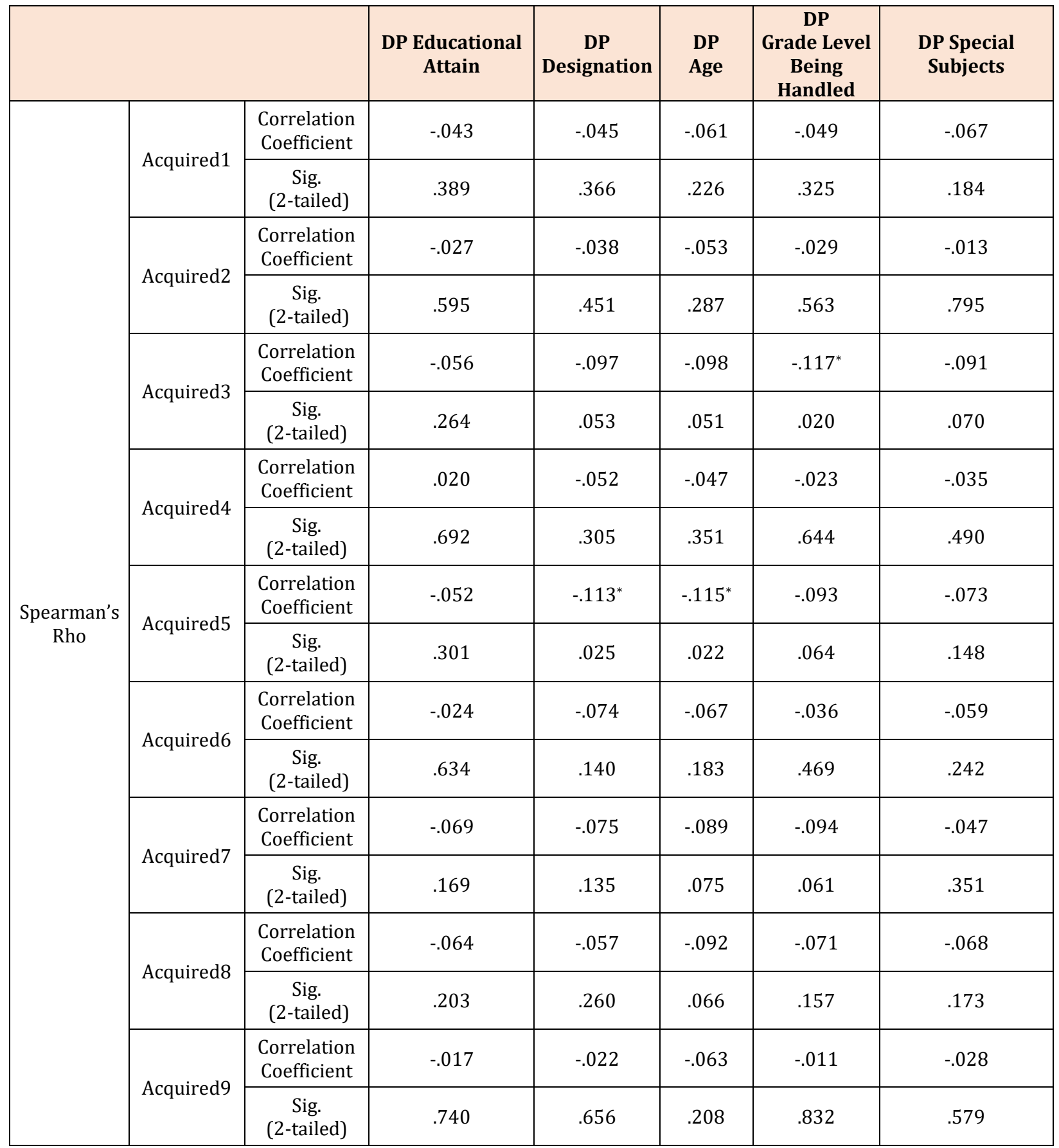

The table above shows the correlation results between the profile of the respondents and their perceptions to the acquired learning of the students.

Based on the results, the following statements under acquired learning have $\mathrm{p} \geq 0.05$ or 0.01 significance level:

The respondents' designation and statement 5, "The learners can transfer their learning concepts to real life situations. This can be seen in their outputs in the new normal.", Grade level handled and statement 3, "The teacher can easily identify whether s/he attained his/ her set objectives by checking the output of the students."
With this, it can be drawn that the position of the respondents has a relationship to their perception on the learners' ability to transfer their learning to real life situations. Their position has a relationship on their analysis to the students' output.

The respondent's grade level that they handle also has a relationship to their perception towards the identification whether a specific objective has been attained during the new normal by checking the output of the students. 
Relationship between Demographic Profile of the Respondents and their Standards in Assessment

TABLE 15: Correlation Table for the Profile of the Respondents and their Standards in Assessment

\begin{tabular}{|c|c|c|c|c|c|c|}
\hline & & $\begin{array}{c}\text { DP } \\
\text { Educational } \\
\text { Attain } \\
\end{array}$ & $\begin{array}{c}\text { DP } \\
\text { Designation }\end{array}$ & $\begin{array}{c}\text { DP } \\
\text { Age }\end{array}$ & $\begin{array}{c}\text { DP } \\
\text { Grade Level } \\
\text { Being Handled } \\
\end{array}$ & $\begin{array}{l}\text { DP Special } \\
\text { Subjects }\end{array}$ \\
\hline \multirow{2}{*}{ Medium1 } & Correlation Coefficient & $-.102^{*}$ & -.062 & -.083 & -.068 & -.021 \\
\hline & Sig. (2-tailed) & .042 & .216 & .099 & .177 & .683 \\
\hline \multirow{2}{*}{ Medium2 } & Correlation Coefficient & .024 & -.040 & -.040 & .002 & -.041 \\
\hline & Sig. (2-tailed) & .632 & .430 & .427 & .961 & .420 \\
\hline \multirow{2}{*}{ Medium3 } & Correlation Coefficient & -.077 & $-.106^{*}$ & $-.110^{*}$ & -.052 & -.069 \\
\hline & Sig. (2-tailed) & .125 & .035 & .028 & .297 & .170 \\
\hline \multirow{2}{*}{ Medium4 } & Correlation Coefficient & .038 & -.006 & .006 & -.006 & .003 \\
\hline & Sig. (2-tailed) & .453 & .908 & .904 & .908 & .957 \\
\hline \multirow{2}{*}{ Medium5 } & Correlation Coefficient & -.046 & -.011 & -.027 & -.079 & .029 \\
\hline & Sig. (2-tailed) & .357 & .823 & .596 & .116 & .565 \\
\hline \multirow{2}{*}{ Medium6 } & Correlation Coefficient & -.069 & -.023 & -.054 & -.070 & -.026 \\
\hline & Sig. (2-tailed) & .169 & .646 & .281 & .162 & .602 \\
\hline \multirow{2}{*}{ Medium7 } & Correlation Coefficient & -.064 & -.051 & -.063 & -.049 & -.004 \\
\hline & Sig. (2-tailed) & .202 & .309 & .212 & .332 & .938 \\
\hline \multirow{2}{*}{ Medium8 } & Correlation Coefficient & -.046 & -.049 & -.062 & -.045 & -.022 \\
\hline & Sig. (2-tailed) & .365 & .325 & .216 & .373 & .661 \\
\hline \multirow{2}{*}{ Medium9 } & Correlation Coefficient & .037 & -.079 & -.057 & .002 & -.057 \\
\hline & Sig. (2-tailed) & .459 & .114 & .258 & .961 & .253 \\
\hline
\end{tabular}

The table above shows the correlation results between the profile of the respondents and their perceptions to the acquired learning of the students.

Based on the results, the following statements under acquired learning have $\mathrm{p} \geq 0.05$ or 0.01 significance level:

The respondents' designation and statement 5, "The learners can transfer their learning concepts to real life situations. This can be seen in their outputs in the new normal.", Grade level handled and statement 3, "The teacher can easily identify whether s/he attained his/ her set objectives by checking the output of the students."

With this, it can be drawn that the position of the respondents has a relationship to their perception on the learners' ability to transfer their learning to real life situations. Their position has a relationship on their analysis to the students' output.

The respondent's grade level that they handle also has a relationship to their perception towards the identification whether a specific objective has been attained during the new normal by checking the output of the students.
In terms of the relationship of the demographic profile and the respondent's standards in assessment, the following showed a significant relationship for their $\mathrm{p} \geq 0.05$ or 0.01 significance level.

Educational attainment and statement 1, "When an output is in a hardcopy (e.g., modules, LAS, etc.), It should be checked more carefully than softcopies (i.e., videos, digital modules/ LAS, etc.)."

Designation and age, and statement 3 , "There should be a maximum grade limit to students today (For instance, all students may have a grade not higher that 95) on the outputs of the new normal."

From the result, it can be noted that the educational attainment of the teachers has a relationship on their perception in checking the output of the students in terms of its form.

Moreover, data shows that the position and age of the teachers influences their standards in terms of setting a grade limit up to what extent that a student might get. 
Relationship Perception towards Student's Output in the New Normal and Standards in Assessment

TABLE 16: Correlation Table for the Relationship between Demographic Profile of the Respondents and their Standards in Assessment

\begin{tabular}{|c|c|c|c|c|c|c|c|c|c|c|}
\hline \multicolumn{11}{|c|}{ Correlations } \\
\hline & & $\begin{array}{c}\text { Medium } \\
1 \\
\end{array}$ & $\begin{array}{l}\text { Medium } \\
2 \\
\end{array}$ & $\begin{array}{c}\text { Medium } \\
3 \\
\end{array}$ & $\begin{array}{c}\text { Medium } \\
4 \\
\end{array}$ & $\begin{array}{c}\text { Medium } \\
5 \\
\end{array}$ & $\begin{array}{c}\text { Medium } \\
6 \\
\end{array}$ & $\begin{array}{c}\text { Medium } \\
7 \\
\end{array}$ & $\begin{array}{c}\text { Medium } \\
8 \\
\end{array}$ & $\begin{array}{c}\text { Medium } \\
9 \\
\end{array}$ \\
\hline \multirow{3}{*}{$\begin{array}{c}\text { Quality } \\
1\end{array}$} & $\begin{array}{l}\text { Correlation } \\
\text { Coefficient }\end{array}$ & $.286^{* *}$ & $.299^{* *}$ & $.169^{* *}$ & $.214^{* *}$ & $.262^{* *}$ & $.214^{* *}$ & $.169^{* *}$ & $.234^{* *}$ & $.275^{* *}$ \\
\hline & $\begin{array}{c}\text { Sig. } \\
\text { (2-tailed) }\end{array}$ & .000 & .000 & .001 & .000 & .000 & .000 & .001 & .000 & .000 \\
\hline & $\mathrm{N}$ & 398 & 398 & 398 & 398 & 398 & 398 & 398 & 398 & 398 \\
\hline \multirow{3}{*}{$\begin{array}{c}\text { Quality } \\
2\end{array}$} & $\begin{array}{l}\text { Correlation } \\
\text { Coefficient }\end{array}$ & $.245^{* *}$ & $.307^{* *}$ & $.182^{* *}$ & $.266^{* *}$ & $.301^{* *}$ & $.275^{* *}$ & $.180^{* *}$ & $.263^{* *}$ & $.289^{* *}$ \\
\hline & $\begin{array}{c}\text { Sig. } \\
\text { (2-tailed) }\end{array}$ & . 000. & .000 & .000 & .000 & .000 & .000 & .000 & . 000. & .000 \\
\hline & $\mathrm{N}$ & 398 & 398 & 398 & 398 & 398 & 398 & 398 & 398 & 398 \\
\hline \multirow{3}{*}{$\begin{array}{c}\text { Quality } \\
3\end{array}$} & $\begin{array}{l}\text { Correlation } \\
\text { Coefficient }\end{array}$ & $.260^{* *}$ & $.228^{* *}$ & $.190^{* *}$ & $.209^{* *}$ & $.263^{* *}$ & $.205^{* *}$ & $.121^{*}$ & $.178^{* *}$ & $.204^{* *}$ \\
\hline & $\begin{array}{c}\text { Sig. } \\
\text { (2-tailed) }\end{array}$ & .000 & .000 & .000 & .000 & .000 & .000 & .016 & .000 & .000 \\
\hline & $\mathrm{N}$ & 398 & 398 & 398 & 398 & 398 & 398 & 398 & 398 & 398 \\
\hline \multirow{3}{*}{$\begin{array}{c}\text { Quality } \\
4\end{array}$} & $\begin{array}{l}\text { Correlation } \\
\text { Coefficient }\end{array}$ & $.194^{* *}$ & $.124^{*}$ & $.175^{* *}$ & $.132^{* *}$ & $.187^{* *}$ & $.274^{* *}$ & $.224^{* *}$ & $.253^{* *}$ & $.256^{* *}$ \\
\hline & $\begin{array}{c}\text { Sig. } \\
\text { (2-tailed) } \\
\end{array}$ & .000 & .013 & .000 & .008 & .000 & .000 & .000 & .000 & .000 \\
\hline & $\mathrm{N}$ & 398 & 398 & 398 & 398 & 398 & 398 & 398 & 398 & 398 \\
\hline \multirow{3}{*}{$\begin{array}{c}\text { Quality } \\
5\end{array}$} & $\begin{array}{l}\text { Correlation } \\
\text { Coefficient } \\
\end{array}$ & $.292^{* *}$ & $.309^{* *}$ & $.213^{* *}$ & $.248^{* *}$ & $.344^{* *}$ & $.226^{* *}$ & $.162^{* *}$ & $.221^{* *}$ & $.247^{* *}$ \\
\hline & $\begin{array}{c}\text { Sig. } \\
\text { (2-tailed) }\end{array}$ & .000 & .000 & .000 & .000 & .000 & .000 & .001. & .000 & .000 \\
\hline & $\mathrm{N}$ & 398 & 398 & 398 & 398 & 398 & 398 & 398 & 398 & 398 \\
\hline \multirow{3}{*}{$\begin{array}{l}\text { Quality } \\
\quad 6\end{array}$} & $\begin{array}{l}\text { Correlation } \\
\text { Coefficient }\end{array}$ & $.125^{*}$ & $.120^{*}$ & .091 & -.045 & .054 & .002 & $.134^{* *}$ & $.162^{* *}$ & .065 \\
\hline & $\begin{array}{c}\text { Sig. } \\
\text { (2-tailed) }\end{array}$ & .013. & .016 & .071 & .374 & .286 & .971 & .008 & .001. & . 198 \\
\hline & $\mathrm{N}$ & 398 & 398 & 398 & 398 & 398 & 398 & 398 & 398 & 398 \\
\hline \multirow{3}{*}{$\begin{array}{c}\text { Quality } \\
7\end{array}$} & $\begin{array}{l}\text { Correlation } \\
\text { Coefficient }\end{array}$ & $.278^{* *}$ & $.302^{* *}$ & $.215^{* *}$ & $.267^{* *}$ & $.293^{* *}$ & $.377^{* *}$ & $.199^{* *}$ & $.275^{* *}$ & $.306^{* *}$ \\
\hline & $\begin{array}{c}\text { Sig. } \\
\text { (2-tailed) }\end{array}$ & .000 & .000 & .000 & .000 & .000 & .000 & .000 & .000 & .000 \\
\hline & $\mathrm{N}$ & 398 & 398 & 398 & 398 & 398 & 398 & 398 & 398 & 398 \\
\hline \multirow{3}{*}{$\begin{array}{c}\text { Quality } \\
\quad 8\end{array}$} & $\begin{array}{l}\text { Correlation } \\
\text { Coefficient }\end{array}$ & $.345^{* *}$ & $.307^{* *}$ & $.241^{* *}$ & $.251^{* *}$ & $.334^{* *}$ & $.420^{* *}$ & $.252^{* *}$ & $.320^{* *}$ & $.344^{* *}$ \\
\hline & $\begin{array}{c}\text { Sig. } \\
\text { (2-tailed) }\end{array}$ & .000 & .000 & .000 & .000 & .000 & .000 & .000 & .000 & .000 \\
\hline & $\mathrm{N}$ & 398 & 398 & 398 & 398 & 398 & 398 & 398 & 398 & 398 \\
\hline \multirow{3}{*}{$\begin{array}{c}\text { Quality } \\
9\end{array}$} & $\begin{array}{l}\text { Correlation } \\
\text { Coefficient } \\
\end{array}$ & $.285^{* *}$ & $.246^{* *}$ & $.163^{* *}$ & $.171^{* *}$ & $.244^{* *}$ & $.294^{* *}$ & $.274^{* *}$ & $.321^{* *}$ & $.245^{* *}$ \\
\hline & $\begin{array}{c}\text { Sig. } \\
\text { (2-tailed) }\end{array}$ & . 000. & .000 & .001 & .001 & . 000. & .000 & .000 & . & .000 \\
\hline & $\mathrm{N}$ & 398 & 398 & 398 & 398 & 398 & 398 & 398 & 398 & 398 \\
\hline \multirow{3}{*}{$\begin{array}{c}\text { Quality } \\
10\end{array}$} & $\begin{array}{l}\text { Correlation } \\
\text { Coefficient }\end{array}$ & $.325^{* *}$ & $.270^{* *}$ & $.198^{* *}$ & $.240^{* *}$ & $.231^{* *}$ & $.186^{* *}$ & $.172^{* *}$ & $.204^{* *}$ & $.241^{* *}$ \\
\hline & $\begin{array}{c}\text { Sig. ( } \\
\text { 2-tailed) }\end{array}$ & .000 & .000 & .000 & .000 & .000 & .000 & .001 & .000 & . 000. \\
\hline & $\mathrm{N}$ & 398 & 398 & 398 & 398 & 398 & 398 & 398 & 398 & 398 \\
\hline \multirow{3}{*}{$\begin{array}{c}\text { Quality } \\
11\end{array}$} & $\begin{array}{l}\text { Correlation } \\
\text { Coefficient }\end{array}$ & $.243^{* *}$ & $.138^{* *}$ & $.245^{* *}$ & $.154^{* *}$ & $.142^{* *}$ & $.289^{* *}$ & $.263^{* *}$ & $.249^{* *}$ & $.210^{* *}$ \\
\hline & $\begin{array}{c}\text { Sig. } \\
\text { (2-tailed) }\end{array}$ & .000 & .006 & .000 & .002 & .005 & .000 & .000 & .000 & .000 \\
\hline & $\mathrm{N}$ & 398 & 398 & 398 & 398 & 398 & 398 & 398 & 398 & 398 \\
\hline \multirow{3}{*}{$\begin{array}{c}\text { Quality } \\
12\end{array}$} & $\begin{array}{l}\text { Correlation } \\
\text { Coefficient }\end{array}$ & $.356^{* *}$ & $.322^{* *}$ & $.295^{* *}$ & $.264^{* *}$ & $.351^{* *}$ & $.409^{* *}$ & $.306^{* *}$ & $.333^{* *}$ & $.372^{* *}$ \\
\hline & $\begin{array}{c}\text { Sig. } \\
\text { (2-tailed) } \\
\end{array}$ & .000 & .000 & .000 & .000 & .000 & .000 & .000 & .000 & .000 \\
\hline & $\mathrm{N}$ & 398 & 398 & 398 & 398 & 398 & 398 & 398 & 398 & 398 \\
\hline
\end{tabular}




\begin{tabular}{|c|c|c|c|c|c|c|c|c|c|c|}
\hline \multicolumn{11}{|c|}{ Correlations } \\
\hline & & $\begin{array}{c}\text { Medium } \\
1 \\
\end{array}$ & $\begin{array}{l}\text { Medium } \\
2 \\
\end{array}$ & $\begin{array}{l}\text { Medium } \\
3 \\
\end{array}$ & $\begin{array}{c}\text { Medium } \\
4\end{array}$ & $\begin{array}{l}\text { Medium } \\
5\end{array}$ & $\begin{array}{l}\text { Medium } \\
6\end{array}$ & $\begin{array}{c}\text { Medium } \\
7 \\
\end{array}$ & $\begin{array}{l}\text { Medium } \\
8 \\
\end{array}$ & $\begin{array}{l}\text { Medium } \\
9\end{array}$ \\
\hline \multirow{3}{*}{$\begin{array}{l}\text { Acquire } \\
\text { d1 }\end{array}$} & $\begin{array}{l}\text { Correlation } \\
\text { Coefficient }\end{array}$ & $.292^{* *}$ & $.347^{* *}$ & $.192^{* *}$ & $.302^{* *}$ & $.343^{* *}$ & $.326^{* *}$ & $.231^{* *}$ & $.360^{* *}$ & $.351^{* *}$ \\
\hline & $\begin{array}{c}\text { Sig. } \\
\text { (2-tailed) }\end{array}$ & .000 & .000 & .000 & .000 & .000 & .000 & .000 & .000 & .000 \\
\hline & $\mathrm{N}$ & 398 & 398 & 398 & 398 & 398 & 398 & 398 & 398 & 398 \\
\hline \multirow{3}{*}{$\begin{array}{l}\text { Acquire } \\
\mathrm{d} 2\end{array}$} & $\begin{array}{l}\text { Correlation } \\
\text { Coefficient } \\
\end{array}$ & $.340^{* *}$ & $.397^{* *}$ & $.293^{* *}$ & $.356^{* *}$ & $.413^{* *}$ & $.395^{* *}$ & $.271^{* *}$ & $.376^{* *}$ & $.326^{* *}$ \\
\hline & $\begin{array}{c}\text { Sig. } \\
\text { (2-tailed) }\end{array}$ & .000 & .000 & .000 & .000 & .000 & .000 & .000 & .000 & .000 \\
\hline & $\mathrm{N}$ & 398 & 398 & 398 & 398 & 398 & 398 & 398 & 398 & 398 \\
\hline \multirow{3}{*}{$\begin{array}{c}\text { Acquire } \\
\text { d3 }\end{array}$} & $\begin{array}{l}\text { Correlation } \\
\text { Coefficient } \\
\end{array}$ & $.356^{* *}$ & $.374^{* *}$ & $.222^{* *}$ & $.323^{* *}$ & $.374^{* *}$ & $.343^{* *}$ & $.264^{* *}$ & $.389^{* *}$ & $.346^{* *}$ \\
\hline & $\begin{array}{c}\text { Sig. } \\
\text { (2-tailed) }\end{array}$ & .000 & .000 & .000 & .000 & .000 & .000 & .000 & .000 & .000 \\
\hline & $\mathrm{N}$ & 398 & 398 & 398 & 398 & 398 & 398 & 398 & 398 & 398 \\
\hline \multirow{3}{*}{$\begin{array}{l}\text { Acquire } \\
\text { d4 }\end{array}$} & $\begin{array}{l}\text { Correlation } \\
\text { Coefficient } \\
\end{array}$ & $.285^{* *}$ & $.410^{* *}$ & $.297^{* *}$ & $.370^{* *}$ & $.432^{* *}$ & $.355^{* *}$ & $.269^{* *}$ & $.381^{* *}$ & $.351^{* *}$ \\
\hline & $\begin{array}{c}\text { Sig. } \\
\text { (2-tailed) }\end{array}$ & .000 & .000 & .000 & .000 & .000 & .000 & .000 & .000 & .000 \\
\hline & $\mathrm{N}$ & 398 & 398 & 398 & 398 & 398 & 398 & 398 & 398 & 398 \\
\hline \multirow{3}{*}{$\begin{array}{l}\text { Acquire } \\
\text { d5 }\end{array}$} & $\begin{array}{l}\text { Correlation } \\
\text { Coefficient } \\
\end{array}$ & $.321^{* *}$ & $.383^{* *}$ & $.294^{* *}$ & $.369^{* *}$ & $.439^{* *}$ & $.404^{* *}$ & $.233^{* *}$ & $.344^{* *}$ & $.318^{* *}$ \\
\hline & $\begin{array}{c}\text { Sig. } \\
\text { (2-tailed) }\end{array}$ & .000 & .000 & .000 & .000 & .000 & .000 & .000 & .000 & .000 \\
\hline & $\mathrm{N}$ & 398 & 398 & 398 & 398 & 398 & 398 & 398 & 398 & 398 \\
\hline \multirow{3}{*}{$\begin{array}{c}\text { Acquire } \\
\text { d6 }\end{array}$} & $\begin{array}{l}\text { Correlation } \\
\text { Coefficient } \\
\end{array}$ & $.270^{* *}$ & $.423^{* *}$ & $.266^{* *}$ & $.374^{* *}$ & $.426^{* *}$ & $.352^{* *}$ & $.216^{* *}$ & $.326^{* *}$ & $.339^{* *}$ \\
\hline & $\begin{array}{c}\text { Sig. } \\
\text { (2-tailed) }\end{array}$ & .000 & .000 & .000 & .000 & .000 & .000 & .000 & .000 & .000 \\
\hline & $\mathrm{N}$ & 398 & 398 & 398 & 398 & 398 & 398 & 398 & 398 & 398 \\
\hline \multirow{3}{*}{$\begin{array}{l}\text { Acquire } \\
\text { d7 }\end{array}$} & $\begin{array}{c}\text { Correlation } \\
\text { Coefficient } \\
\end{array}$ & $.316^{* *}$ & $.385^{* *}$ & $.246^{* *}$ & $.309^{* *}$ & $.415^{* *}$ & $.406^{* *}$ & $.228^{* *}$ & $.401^{* *}$ & $.340^{* *}$ \\
\hline & $\begin{array}{c}\text { Sig. } \\
\text { (2-tailed) }\end{array}$ & .000 & .000 & .000 & .000 & .000 & .000 & .000 & .000 & .000 \\
\hline & $\mathrm{N}$ & 398 & 398 & 398 & 398 & 398 & 398 & 398 & 398 & 398 \\
\hline \multirow{3}{*}{$\begin{array}{l}\text { Acquire } \\
\text { d8 }\end{array}$} & $\begin{array}{l}\text { Correlation } \\
\text { Coefficient } \\
\end{array}$ & $.366^{* *}$ & $.417^{* *}$ & $.343^{* *}$ & $.369^{* *}$ & $.485^{* *}$ & $.516^{* *}$ & $.306^{* *}$ & $.424^{* *}$ & $.431^{* *}$ \\
\hline & $\begin{array}{c}\text { Sig. } \\
\text { (2-tailed) }\end{array}$ & .000 & .000 & .000 & .000 & .000 & .000 & .000 & .000 & .000 \\
\hline & $\mathrm{N}$ & 398 & 398 & 398 & 398 & 398 & 398 & 398 & 398 & 398 \\
\hline \multirow{3}{*}{$\begin{array}{l}\text { Acquire } \\
\text { d9 }\end{array}$} & $\begin{array}{l}\text { Correlation } \\
\text { Coefficient } \\
\end{array}$ & $.240^{* *}$ & $.418^{* *}$ & $.340^{* *}$ & $.341^{* *}$ & $.402^{* *}$ & $.419^{* *}$ & $.264^{* *}$ & $.371^{* *}$ & $.400^{* *}$ \\
\hline & $\begin{array}{c}\text { Sig. } \\
\text { (2-tailed) } \\
\end{array}$ & .000 & .000 & .000 & .000 & .000 & .000 & .000 & .000 & .000 \\
\hline & $\mathrm{N}$ & 398 & 398 & 398 & 398 & 398 & 398 & 398 & 398 & 398 \\
\hline
\end{tabular}

The table above shows the results in determining the correlation between the standards of teacher in the new normal and their perceptions to the output of the students.

Based from the data, there is relationship between the perception of the teachers to the quality of output of the students and the teachers' standards in assessing their students (because the $p$ value $\geq 0.05$ or 0.01 of level of significance). The $\mathrm{p}$ value of the those which have significant relationships is ranging from $0.000-0.008$. This means that there is strong correlation between the perception of the teachers on the students' output and their standards in checking.

However, the statement 6 under quality does not correlate to statements $3,4,5,6$, and 9 on the standards of assessment of the teachers.

In terms of the acquired learning of the students, results show that it has a perfect correlation with the teachers' standards in assessment. The $\mathrm{p}$ value $\geq 0.01$ or 0.05 significance level). The table shows a $0.00 \mathrm{p}$ value, indicating a perfect correlation.

\section{SUMMARY, CONCLUSIONS AND RECOMMENDATIONS}

This part of the study presents the summary, conclusions and recommendations of the research.

\section{SUMMARY}

This study is entitled, "Medium as a Variable to the Teachers' Subjectivity in Assessment in the New Normal." This study aims to determine whether the medium which, as defined in this study, is the channel or form of assessment of the students - influences the teachers' subjectivity.

The study sought to determine the profile of the respondents. Their age, teaching position, educational attainment, grade level handled and district were gathered. 
The study also sought to determine the assessment practice of the teacher - respondents by determining the teachers' frequency of checking, medium of output of the students, the assessment instrument used and the modalities in which assessment goes through.

The perception of the teacher - respondents on the output in the new normal was determined so also as their standards in assessment. After gathering necessary data, they were correlated.

Results show that the most of the respondents have an age ranging from 21 - 40; most of them are teacher I and teacher III and finished Bachelor's degree as their highest educational attainment.

The research used convenience sampling as its sampling method. Out of 12, 545 teachers in the Division of Nueva Ecija, 398 respondents have been considered as samples. $61.05 \%$ of the respondents are teaching in the elementary.

The respondents are not handling special programs and they came from different SDO - Annexes.

In terms of the assessment practices of the teacher respondents, almost half of the respondents check the output of the students once a week.

Those who check weekly consumes 1 - 4 hours checking the output of the students.

The outputs of the students are that which are accessible to them - hardcopies, chats, text messages, mobile calls, and video calls. Because of this, the assessment instrument used by the teachers are multiple choices, true or false, matching type, essay, filling in the blanks, and enumeration; all of which are found on the medium preference of the students.

For the perception of teachers on the quality of output of the students in the new normal, respondents agree that the output before the pandemic is better than the normal. They agree that the parents help their children in accomplishing their outputs, making the outputs better. They perceive that the contents of the student's output are of good quality because they agree that the students are doing their best in accomplishing the outputs. Results say that the respondents agree that the teachers can evidently see the diligence of their students. They agree that the students spend much time to comply the outputs.

However, respondents perceive that the students' output are for compliance alone. They also still believe that the parents are the ones who do the outputs of the students. This can be justified because the respondents see that the outputs of the students in the new normal enhanced.

For their perception in terms of the acquired learning of the students in the new normal vis-à-vis assessment, the teachers agree that from the outputs, they can easily determine whether they have accomplished their set objective. Based from the teachers, the learners can transfer the learning concepts in situations because they agree that discovery learning is evidently seen on the output of the students.

Distance learning does not hinder the students to learn $21^{\text {st }}$ century skills according to the teachers and their creativity can still be showcased.

For the students critical thinking, the teachers agree that it can be seen from the outputs of the students.
The teachers agree that cognitive, psychomotor and effective skills can be evidently seen in the output of the students. Moreover, they agree that the students develop ICT skills than content skills.

For the teachers' standards in assessing the output of the students in the new normal, teachers agree that when an output is in a hardcopy, it should be checked more carefully than softcopies.

They also agree that there should be maximum and minimum limit in giving grades on the students' output. Also, they agree that there are times wherein the teachers should not only rely on the rubrics. This is because they believe that checking should focus more on effort than the content of the outputs making them agree that the effort of the students should also be graded; once that the students have submitted their output, it should be automatically graded.

The reason for this is that the teachers believe that subjectivity is important than being objective in assessing the students' output.

In case that there is an error on the output of the students, they agree that the output should not be returned. The students should have a grade instead.

In the correlation, it was found that the designation and age of the teachers has a relationship to their perception regarding on being appreciative on efforts exerted of the students.

However, results show that there is no general correlation between the demographic profile of the teachers and perceptions on the quality of outputs in the new normal.

For the teachers' perception on the acquired learning of the students and its relationship to their demographic profile, the designation of the teacher has a relationship to their perception that the outputs of the students can indicate whether the students have applied their learning in real life concepts. Moreover, their designation has also a relationship to their perception regarding the determination of success of the set objectives.

However, generally, there is no significant relationship between the demographic profile of the teachers and their perception towards the acquired learning of the students vis-à-vis assessment in the new normal.

In terms of the relationship between the teachers' profile and its relationship to the standards assessment of teachers, it was found that the teachers' educational attainment and their preference what to be checked more carefully - hardcopy or softcopy - shows a significant relationship.

The teachers' designation and age also have a relationship to the standards of giving a maximum grade limit to the students.

However, there is no significant relationship between the demographic profile of the teachers and their standards in assessment in general.

For the relationship of the teachers' perception to the output of the students and their standards of assessment. It was found out that there is a significant relationship between the two. 


\section{CONCLUSIONS}

From the summary of findings of this study, the following conclusions were drawn:

The respondents' ages are ranging from $21-40$. Since teachers' in this age are more engaged in technology, they were the one who were able to join as respondents of the study.

Most respondents are teacher I and teacher III. Such designations are common to public school. Half of the respondents are teacher III. This can be rooted to the respondents' highest educational attainment, who, are mostly bachelors but many of whom have units in masters.

Half of the respondents were from elementary level. This is because of the sampling design used by this study, convenience sampling.

$76 \%$ of the respondents are not handling special programs. This is because not all schools offer such.

For the assessment practice of teachers, most respondents check outputs once a week and usually spends $1-4$ hours checking. This is because of the other workloads that they have to do such as reports, distribution and retrieval of modules and remotely meeting the students.

The preference of the form of output of the teachers depends on the resources available to the students and parents. That is why, the teachers have to adjust the type of assessment that they are giving to the students.

It was found that is a relationship between the medium of output of the students, and the designation, grade level and program being handled, and age of the respondents.

In terms of checking, the designation of the respondents shows a relationship to their frequency of checking.

It is noted in the results that teachers use objective tests that mostly promote LOTS or lower thinking skills. This is because of the consideration that they give on the part of the students. They believe that complex assessment would be difficult to the students because they are not physically meeting them.

This study shows that there is a perception already before checking the outputs of the students. They anticipate that the students exert effort in accomplishing their outputs but they also believe that there are times that the parents are the ones who accomplish the outputs. They also perceive that outputs in the new normal are for compliance alone.

Because of this, they put maximum and minimum grade limit to the grades of the students. Also, since they believe that the outputs are for compliance, they automatically give grades to the students whether the content is right or wrong. This is because of their perception that subjectivity is more important than being objective in assessment.

Results show that there is significant relationship to the perception of the teachers to the output of the students in the new normal and their standards in assessment.

External forces and challenging situations influence the teachers in their standards. However, this is in contrast to the principle of DO 8, s. 2015 and DO 31, s. 2020 that assessment should be used to inform and improve practices and learning outcomes. Assessment is the key in determining the learner's achievement and should not be for compliance per se to promote a student.

\section{RECOMMENDATIONS}

Armed with conclusions of the study, the following recommendations can be considered:

- There should be a training on assessment subjectivity and objectivity. The teachers should have a clear idea on assessment and the limits of consideration to students.

- The guidelines for failing, dropping out and promotion should be reiterated to the teachers so that the clouds of questions regarding such will be resolved.

- Training on strategies in remote assessment may be considered. This time, the administrative should be the ones who should facilitate the workshop.

- The division office may consider reviewing the resources of the schools and their stakeholders. With this, the challenges that are being faced by parents and students might be addressed properly.

- If possible, a pass-or-fail-system should be implemented in grading the students. With such, teachers will not have to worry regarding the numerical remarks that they have to put to indicate the academic achievement of the students.

- A related study should be conducted using stratified random sampling so that an equal number of teachers from different levels will be the respondents. Thus, they will be given an equal chance to have their perception recorded regarding assessment.

- Future studies that qualitatively on focus the factors that influence teachers' subjectivity may be considered.

- Moreover, the division office may consider studying the underlying concept of promoting students in public schools.

\section{REFERENCES}

[1] Universal Declaration of Human Rights. (n.d.). Retrieved September 28, 2020, from https://www.un.org/en/universal-declarationhuman-rights/

[2] THE 1987 CONSTITUTION OF THE REPUBLIC OF THE PHILIPPINES - ARTICLE XIV: GOVPH. (n.d.). Retrieved September 28, 2020, from https://www.officialgazette.gov.ph/constitutions/t he-1987-constitution-of-the-republic-of-thephilippines/the-1987-constitution-of-the-republicof-the-philippines-article-xiv/

[3] DO 012, 2020 - Adoption of the Basic Education Learning Continuity Plan for School Year 2020-2021 in the Light of the COVID-19 Public Health Emergency. (n.d.). Retrieved September 28, 2020, from https://www.deped.gov.ph/2020/06/19/june-192020-do-012-2020-adoption-of-the-basiceducation-learning-continuity-plan-for-school-year2020-2021-in-the-light-of-the-covid-19-publichealth-emergency/

[4] Batas Pambansa Blg. 232 - Education Act of 1982. (n.d.). Retrieved September 28, 2020, from https://www.lawphil.net/statutes/bataspam/bp19 82/bp_232_1982.html 
[5] DO 021, s. 2019 - Policy Guidelines on the K to 12 Basic Education Program. (n.d.). Retrieved September 28, 2020, from https://www.deped.gov.ph/2019/08/22/august22-2019-do-021-s-2019-policy-guidelines-on-the-kto-12-basic-education-program/

[6] Learning Delivery Module 2. Module 3a attachment in supplementary materials. Pdf

[7] Ramos, C. (2020, June 25). Only 4 out of 10 teachers trained so far for distance learning, DepEd tells senators. Retrieved September 28, 2020, from https://newsinfo.inquirer.net/1297181/only-4-outof-10-teachers-trained-so-far-for-distance-learningdeped-tells-senators

[8] The Star Online. (2020, April 27). Transitioning to the new normal in education. Retrieved September 28, 2020, from

https://www.thestar.com.my/opinion/letters/2020 /04/28/transitioning-to-the-new-normal-ineducation

[9] DO 8, s. 2015 - Policy Guidelines on Classroom Assessment for the K to 12 Basic Education Program. (n.d.). Retrieved September 28, 2020, from https://www.deped.gov.ph/2015/04/01/do-8-s2015-policy-guidelines-on-classroom-assessmentfor-the-k-to-12-basic-education-program/

[10] Assessment For, As, and Of Learning. (n.d.). Retrieved September 28, 2020, from https://teachingcommons.lakeheadu.ca/assessment -and-learning

\section{[11] Alternative Learning Delivery Mode Standards.pdf}

[12] Couchenour, D., \& Chrisman, J. K. (2016). The SAGE Encyclopedia of Contemporary Early Childhood Education. doi:10.4135/9781483340333

[13] Meissel, K., Meyer, F., Yao, E. S., \& Rubie-Davies, C. M. (2017). Subjectivity of teacher judgments: Exploring student characteristics that influence teacher judgments of student ability. Teaching and Teacher Education, 65, 48-60.

doi: $10.1016 /$ j.tate.2017.02.021

[14] Fraenkel, J. R., Wallen, N. E., \& Hyun, H. H. (2013). How to design and evaluate research in education 8th Edition. New York: McGraw-Hill

[15] Sampling Demystified: Probability vs. NonProbability Sampling. Retrieved September 28, 2020, from

https://www.cvent.com/en/blog/events/samplingdemystified-probability-vs-non-probabilitysampling

[16] Convenience sampling - Research Methodology. (n.d.). Retrieved September 28, 2020, from https://research-methodology.net/sampling-inprimary-data-collection/convenience-sampling/
[17] https://stats.idre.ucla.edu/spss/faq/what-doescronbachs-alpha-mean/

[18] Middleton, F. (2020, June 26). The 4 Types of Reliability: Definitions, Examples, Methods. Retrieved September 28, 2020, from https://www.scribbr.com/methodology/types-ofreliability/

[19] Stephanie. (2020, August 03). Weighted Mean: Formula: How to Find Weighted Mean. Retrieved September 28, 2020, from https://www.statisticshowto.com/weighted-mean/

[20] Wayne, Andrew \& Youngs, Peter. (2003). Teacher Characteristics and Student Achievement Gains: A Review. Review of Educational Research. 73. 89-122. 10.3102/00346543073001089.

[21] Shah, Shilpa \& Udgaonkar, Usha. (2018). Influence of Gender and Age of Teachers on Teaching: Students Perspective. International Journal of Current Microbiology and Applied Sciences. 7. 2436-2441. 10.20546/ijcmas.2018.701.293.

[22] Interim Guidelines for Assessment and Grading in Light of the BE - LCP (DepEd Order 31, s. 2020)

\section{ACKNOWLEDGMENT}

The researcher would like to acknowledge the God Almighty who had given him knowledge and wisdom to finish this research. Moreover, this research would not be made without the help of the following individuals:

The research approving committee of the Department of Education - Schools Division of Nueva Ecija: Jessie D. Ferrer, CESO V, Schools Division Superintendent, Mina Gracia L. Acosta, PhD., CESO V, and Ronilo E. Hilario, CESE, Assistant Schools Division Superintendents, Jayne M. Garcia, EdD, Curriculum Implementation Division Chief, Luis M. Calison, School Governance and Operations Division Chief, Mauricio F. Angeles, Senior Education Program Specialist I, and Ma. Checilia M. Bagsic, PhD for allowing the proponent to conduct the study in the provincial division of Nueva Ecija.

The researcher's mentor, Laberne A. Ladignon, Jr., Education Program Supervisor, for the support and help in reaching the respondents of the study.

Dr. Mario Quiambao and all the Public-School District Supervisors in DepEd - Nueva Ecija, in helping the proponent administering the questionnaires to the respodents.

Josefina R. Roque, the former school principal of Magpapalayok National High School, Jenny Lynn T. Batoy, the proponent's current school principal, and Emilia D. Mauricio, the proponent's department head for the throughout support in completing the research paper, from conceptualization up to publication.

Lastly, the researcher's parents: Protacio and Gloria Garcia, sibling, Albert Sam Garcia, and love of his life, Myra V. Dela Cruz for the never-ending support and prayers to the proponent's every endeavor 